JOURNAL OF SECURITY AND SUSTAINABILITY ISSUES

ISSN 2029-7017 print/ISSN 2029-7025 online

2019 June Volume 8 Number 4

http://doi.org/10.9770/jssi.2019.8.4(20)

Scopus

\title{
USE OF CONSOLIDATION STRATEGIES IN ORDER TO IMPROVE THE CORPORATE SECURITY: METHODOLOGICAL ASPECT
}

\author{
Maryna Chorna $^{1}$, Roman Buhrimenko ${ }^{2}$, Polina Smirnova ${ }^{3}$, Svetlana Shynkar ${ }^{4}$, Iryna Zhuvakina ${ }^{5}$ \\ ${ }^{1 * 2,3,4}$ Kharkov State University of Food Technology and Trade, Klochkovska street, 333, Kharkiv, 61055, Ukraine \\ ${ }^{5}$ National University of Shipbuilding named after Admiral Makarov, Odeska Str., 107, Pervomaysk, 55200, Ukraine
}

E-mail:1*lubanes@gmail.com

Received 15 December 2018; accepted 13 May 2019; published 30 June 2019

\begin{abstract}
The scientific work is devoted to the issue of sustainable development of various corporate structures in order to increase their level of security through the use of consolidation strategies. The econometric modeling of the use of the strategic approach in the corporate consolidation of business structures has been carried out; the indicators of corporate governance estimate on the pre-integration phase have been proposed. The model of corporatization of corporate structures and the growth of the level of corporate security within the framework of consolidation strategies have been developed based on the emergent effect of the new structure. The methodical approach has been formed in order to optimize the choice of business structures that claim to become part of the consolidated system.
\end{abstract}

Keywords: corporation; corporate security; level of corporate governance; consolidation strategy; integration; strategic management; investor; profitability index (PI)

Reference to this paper should be made as follows: Chorna, M.; Buhrimenko, R.; Smirnova, P, Shynkar, S., Zhuvakina, I. 2019. Use of consolidation strategies in order to improve the corporate security: methodological aspect, Journal of Security and Sustainability Issues 8(4): 783-798. http://doi.org/10.9770/jssi.2019.8.4(20)

JEL Classifications: M16, P11

\section{Introduction}

The core of strategic management, which must provide long-term sustainable development and proper organizational and economic security within the corporate structure, is the process of developing and implementing a common strategy. The modern corporate level is carried out in conditions of increased instability and uncertainty of factors of the environment. This leads to imbalance, which manifests itself, above all, in the failure of the board of the company of its functions and disproportions in the distribution of power. It is the set of reasons that determines the importance of strategic management of the development and transformation of corporate structures under the influence of changes in qualitative and quantitative characteristics of the factors of the external international and national environment. It also stipulates the use of a practical tool for strategic management in the "strategy-corporate security" system, which is presented in detail in such research papers (Acur, and Englyst, 2006; Collis, and Cynthia, 2005; Cravens, and Piercy, 2009; Dodgson, 2018; Hitt, et al. 2007; Hu, and Izumida, 2008; Rothaermel, 2015; Ardalan et al., 2017; Kordík and Kurilovská, 2019; Kazansky and Andrassy, 2019; Hasanudin et al., 2019).

We can assert that the strategy developed for the future period combines the strategies of integrated and diversified growth. The development of domains, which are close to the main products, can be formulated as the directions of diversification. The presented aspects of application of the strategic approach have formed the methodological basis of development processes and security of functioning of corporate structures on the basis of consolidation strategies. 


\section{Methodology of research}

Let us make modeling of the application of the strategic approach in corporate consolidation. We introduce a number of indicators in order to assess the quality of corporate governance. In order to assess the general set of entrepreneurial structures in consolidation, we use the half-sum of the smallest and largest values of this set:

$$
x_{c e p}=0,5 \times\left(x_{1}+x_{n}\right)
$$

- The arithmetic mean of all observations:

$$
\bar{x}=\frac{1}{n} \sum_{i=1}^{n} x_{i}
$$

In order to decide which estimate is more acceptable, it is necessary to determine the properties of statistical estimates. The most important ones are:

- Bias of an estimator.

An estimate $\bar{a}_{n}=\overline{a_{n}}\left(x_{1}, \ldots . x_{n}\right)$ is unbiased if its mathematical expectation is equal to the actual value of the parameter:

$$
M\left(a_{n}=a_{n}\left(x_{1}, \ldots . x_{n}\right)\right)=a
$$

- Capability.

Let us assume that $\bar{a}_{n}=\overline{a_{n}}\left(x_{1}, \ldots \ldots x_{n}\right)$. The estimate of the parameter $a$ is called capable, if the probability of a significant deviation from $a_{n} a$ tends to zero when $n \rightarrow \infty$, then for any $E>0$, the condition is fulfilled:

$$
P\left(\left|a_{n}-a\right|<E\right) \rightarrow 1 \text {, when } n \rightarrow \infty,
$$

- Efficiency.

The unbiased estimate $\bar{a}_{n}=\overline{a_{n}}\left(x_{1}, \ldots . x_{n}\right)$ is called effective if it has the smallest dispersion among the unbiased estimates of the parameter $a$ by a sample of volume $n$.

The arithmetic mean found in the sample is usually considered as an estimate of value $a$ :

$$
x^{-}=\frac{1}{n} \sum_{i=1}^{n} x_{i}
$$

- Sample mean.

From the law of large numbers it turns out that such an estimate is capable, that is, the value $X_{n}$ tends to $a$ when $n \rightarrow \infty$.

Let us find the mathematical expectation of the sample mean: 


$$
M\left(\begin{array}{l}
- \\
x_{n}
\end{array}\right)=M\left(\frac{1}{n} \sum_{i=1}^{n} x_{i}\right)=\frac{1}{n} \sum_{i=1}^{n} M\left(x_{i}\right)=\frac{1}{n} n a=a
$$

It coincides with the value of $a$. This means that the sample mean is an unbiased estimate of the mathematical expectation. In the case of a normal distribution of the general set, the value of $\mathcal{X}_{6}$ is also an effective estimate.

\section{Assessment of the level of corporate governance while ensuring corporate security}

The overall rating depends on the most important criteria that affect the level of corporate governance, namely (Bradley, and Sundaram, (2006; Kiymaz, and Baker, 2008; Douma, et al. 2006; Drobyazko S., 2018a,b):

1. The corporation's readiness to adhere to the principles of corporate behavior;

2. Structure of corporate property;

3. General Meeting of Shareholders;

4. Board of Directors of the Corporation (Supervisory Board);

5. Executive authority;

6. Corporate secretary;

7. Significant corporate actions;

8. Disclosure by corporation;

9. Corporate Shareholder Register;

10. Control over financial and economic activity of the corporation;

11. Dividend policy of the corporation;

12. Corporate Conflict Resolution.

The estimate of each of the 12 criteria is based on open and accessible information, fixed:

- in the annual report of the corporation;

- in the quarterly report of issuers of securities;

- in reports on significant facts (events) affecting financially, namely the economic activity of the issuer of issuance securities;

- in the news feed of news agencies;

- on the official website of the corporation;

- in the information provided by the corporation;

- in the information of the general meeting of shareholders; etc.

The methodology for assessing the level of corporate governance makes it possible to get a quantitative assessment separately for each of the 12 indicators and the overall corporate governance as a whole. Each indicator consists of a set of criteria characterizing the company's activities. The assessment is based on the opinion of the respondent, which is expressed in the determination of the weighting factor (from 0 to 1 ) for each criterion (Vachon, 2007).

When calculating the level of corporate governance, the following factors are used:

$-i$ - ordinal index of the indicator, $i=1,2,3 \ldots 12$;

$-j-$ ordinal index of the criterion in the indicator, $j=1,2,3 \ldots 12$;

$-\mathrm{A}_{i j}$ - the coefficient of compliance of the existing corporate governance criterion $j$ of the indicator $i$. Where 0 means the criterion is not implemented in the corporation, 1 means the criterion is fully implemented in the corporation;

$-B_{i j}$ - the weight of the indicator $i$ in criterion $j$, according to the respondent. Where 0 means the criterion is not implemented in the corporation, 1 means the criterion is fully implemented in the corporation;

$-C_{i j}$ - the weight of the indicator $i$ in criterion $j$, calculated on the basis of the data of the activities of the companies;

$-D_{i j}$ - coefficient of compliance with the criterion $j$ for assessing the level of corporate governance of the company under study by the calculation criterion; 
$-E_{i j}$ - coefficient of compliance with the criterion $j$ for assessing the level of corporate governance of the company under study according to the respondent;

$-N_{j}$ - the value of the criterion $j$ for assessing the level of corporate governance determined on the basis of data of the companies;

$-M_{j}$ - the value of the criterion $j$ for assessing the level of corporate governance determined according to the respondent;

$-G_{j}$ - the value of the level of the criterion $j$, determined on the basis of the data of the activities of the companies;

$-H_{j}$ - the value of the level of the criterion $j$, determined according to the respondent's data;

$-K$ - the level of corporate governance in the corporation, determined on the basis of business activity data;

$-L-$ the level of corporate governance in the corporation, determined according to the respondent.

The final assessment of the level of corporate governance is expressed in percentages $(100 \%$ is the highest level of corporate governance, $0 \%$ is the lowest level of corporate governance) and is formed by summing up the final results for each of the 12 indicators (Table 1). An assessment is made by the Board of Directors of the corporate structure, in order to determine the efficiency of the system of corporate relations.

Table 1. Assessment of the level of corporate governance in ensuring corporate security

\begin{tabular}{|c|c|c|c|c|c|c|}
\hline $\begin{array}{c}\text { \# of } \\
\text { indicator } \\
i j\end{array}$ & $\begin{array}{c}\text { Criteria for assessing } \\
\text { the level of corporate } \\
\text { governance }\end{array}$ & $\begin{array}{c}\text { Coefficient } \\
\text { from } 0 \text { to } 1, \\
A_{i j}\end{array}$ & $\begin{array}{c}\text { Weight of the } \\
\text { criterion according } \\
\text { to the respondent) } \\
\text { from } 0 \% \text { to } 100 \%, \\
B_{i j}\end{array}$ & $\begin{array}{c}\text { Weight } \\
\text { criterion } \\
C_{i j}\end{array}$ & $\begin{array}{c}\text { Total, } \\
D_{i j}=A_{i j} C_{i j}\end{array}$ & $\begin{array}{c}\text { Total, } \\
E_{i j}=A_{i j} \mathrm{x} B_{i j} \\
\text { (according to the } \\
\text { respondent) }\end{array}$ \\
\hline 1 & 2 & 3 & 4 & 5 & 6 & 7 \\
\hline $\mathrm{x}$ & $\mathrm{x}$ & $\mathrm{x}$ & $\mathrm{x}$ & $\mathrm{x}$ & $\mathrm{x}$ & $\mathrm{x}$ \\
Comment \\
$\mathrm{y}$
\end{tabular}

Source: Enterprise Risk Management-Integrated Framework: Executive Summary (2004)

Each of the indicators has its weight as a result of the analysis of violations of the law and the code of corporate behavior in the field of corporate structure (Petrishcheva, 2011). Let us calculate the quality of corporate governance on an example and according to the Pharmcare company of the pharmaceutical industry (Table 2).

Table 2. Corporate governance indicators of Pharmcare Company for the period of 2013-2017.

\begin{tabular}{|c|c|c|c|c|c|c|}
\hline \multirow{2}{*}{$\begin{array}{c}\text { \# of } \\
\text { indicator }\end{array}$} & \multirow{2}{*}{ Corporate governance indicators } & \multicolumn{5}{|c|}{ Years } \\
\hline & & 2013 & 2014 & 2015 & 2016 & 2017 \\
\hline 1 & The corporation's readiness to adhere to the principles of corporate behavior & 1 & 2 & 3 & 2 & 2 \\
\hline 2 & Structure of corporate property & 6 & 5 & 4 & 2 & 4 \\
\hline 3 & General Meeting of Shareholders & 17 & 15 & 13 & 13 & 14 \\
\hline 4 & Board of Directors of the Corporation & 10 & 10 & 12 & 10 & 11 \\
\hline 5 & Executive authority & 9 & 11 & 9 & 10 & 10 \\
\hline 6 & Corporate secretary & 8 & 6 & 7 & 9 & 8 \\
\hline 7 & Significant corporate actions & 5 & 10 & 8 & 6 & 7 \\
\hline 8 & Disclosure by corporation & 13 & 12 & 13 & 12 & 11 \\
\hline 9 & Corporate Shareholder Register & 12 & 16 & 15 & 14 & 15 \\
\hline 10 & Control over financial and economic activity of the corporation & 4 & 4 & 5 & 3 & 4 \\
\hline 11 & Dividend policy of the corporation & 7 & 3 & 4 & 9 & 6 \\
\hline 12 & Corporate Conflict Resolution & 8 & 6 & 7 & 10 & 8 \\
\hline & Total: & 100 & 100 & 100 & 100 & 100 \\
\hline
\end{tabular}


The final result of the significance of the indicator assessment of the level of corporate governance for Pharmcare Corporation is calculated as the arithmetic mean of the values of corporate governance indicators based on the results of a specified time period (Table 3).

Table 3. The final value of the corporate governance indicator

\begin{tabular}{|c|l|c|}
\hline $\begin{array}{c}\text { \# of } \\
\text { indicator }\end{array}$ & \multicolumn{1}{|c|}{ Corporate governance indicators } & $\begin{array}{c}\text { Significance of the indicator } \\
\text { and the level of corporate } \\
\text { governance, } C_{i} \%\end{array}$ \\
\hline 1 & The corporation's readiness to adhere to the principles of corporate behavior & 2 \\
\hline 2 & Structure of corporate property & 4,2 \\
\hline 3 & General Meeting of Shareholders & 14,4 \\
\hline 4 & Board of Directors of the Corporation & 10,6 \\
\hline 5 & Executive authority & 9,8 \\
\hline 6 & Corporate secretary & 7,6 \\
\hline 7 & Significant corporate actions & 7,2 \\
\hline 8 & Disclosure by corporation & 12,2 \\
\hline 9 & Corporate Shareholder Register & 14,4 \\
\hline 10 & Control over financial and economic activity of the corporation & 4 \\
\hline 11 & Dividend policy of the corporation & \\
\hline 12 & Corporate Conflict Resolution & 5,8 \\
\hline & Total: & 7,8 \\
\hline
\end{tabular}

Source: Statistics on M\&A deals, 2018, calculation authors

Similarly, the weightings of the criteria for each of the indicators are determined $\left(\mathrm{C}_{i j}\right)$.

In order to determine the level of corporate governance, respondents need to assess how corporate governance of the corporation concerned meets the criteria set out in column 2 of Table 1 . In column 3, the value of conformity $\left(A_{i j}\right)$ from 0 (criterion is not executed) to 1 (criterion is executed completely) is fixed.

The method allows respondents to specify their own weighting factors in column 4 of the table $\left(B_{i}, B_{i j}\right)$ based on its criteria, taking into account the specifics of a particular company (Alam, et al. 2014; Makedon, and Korneyev, 2014).

The level of corporate governance is calculated in the following order:

1. The respondent evaluates how much, in his opinion, the criterion for assessing the level of corporate governance, recorded in column 2 of the table is performed by the corporation. Score $\left(A_{i j}\right)$ from 0 (criterion is not executed) to 1 (criterion is executed completely) is fixed in the corresponding cell.

2. The respondent needs to determine which weight of the criteria will be used when calculating the level of corporate governance:

- methodology proposed by the authors $\left(C_{i j}\right)$;

- methodology proposed by the respondent taking into account the specifics of a particular company. In this case, one must specify the weight of the criteria $\left(B_{i j}\right)$. By default, the calculated weights are as component weights $B_{i}$. They can also be changed at the request of the respondent (Thompson, 2010).

3. Subsequent actions are performed by the program automatically, namely:

a. The calculation is made of how much the level of corporate governance meets a specific criterion (depending on the weights used) (formulas (6-7):

$$
D_{i j}=A_{i j} C_{i j}, i=1,2 \ldots \quad j=1,2 \ldots 12
$$




$$
E_{i j}=A_{i j} B_{i j}, \quad i=1,2 \ldots \quad j=1,2 \ldots 12
$$

b. The calculation is made of how much the level of corporate governance meets a specific component (depending on the weights used) (formulas (8-9):

$$
\begin{gathered}
G_{i}=\frac{\sum D_{i j} \times C_{i j}}{100}, j=1,2 \ldots 12 \\
H_{i}=\frac{\sum E_{i j} \times B_{i j}}{100}, j=1,2 \ldots 12
\end{gathered}
$$

c. The total level of corporate governance is calculated (depending on the weights used) (formulas (10-11):

$$
\begin{aligned}
& K_{1}=\sum G_{i}, \quad i=1,2 \ldots 12 \\
& K_{2}=\sum H_{i}, \quad i=1,2 \ldots 12
\end{aligned}
$$

\begin{tabular}{|c|c|c|}
\hline \multirow{2}{*}{$\begin{array}{l}\text { Criteria for assessing the level } \\
\text { of corporate governance }\end{array}$} & $\begin{array}{l}\text { Control value of corporate } \\
\text { governance indicator }\end{array}$ & $\begin{array}{l}\text { Control value of the corporate } \\
\text { governance indicator, taking into account } \\
\text { the weights of the respondent }\end{array}$ \\
\hline & $\begin{array}{l}\text { Calculated value of the } \\
\text { corporate governance } \\
\text { indicator }\end{array}$ & $\begin{array}{l}\text { Calculated value of the corporate } \\
\text { governance indicator, taking into account } \\
\text { the weights of the respondent }\end{array}$ \\
\hline \multirow{2}{*}{$\begin{array}{l}\text { The corporation's readiness to adhere to the principles of } \\
\text { corporate behavior }\end{array}$} & 2 & 2 \\
\hline & 0 & 0 \\
\hline \multirow{2}{*}{ Structure of corporate property } & 4,2 & 4,2 \\
\hline & 0 & 0 \\
\hline \multirow{2}{*}{ General Meeting of Shareholders } & 14,4 & 14,4 \\
\hline & 0 & 0 \\
\hline \multirow{2}{*}{ Board of Directors of the Corporation } & 10,6 & 10,6 \\
\hline & 0 & 0 \\
\hline \multirow{2}{*}{ Executive authority } & 9,8 & 9,8 \\
\hline & 0 & 0 \\
\hline \multirow{2}{*}{ Corporate secretary of the corporation } & 7,6 & 7,6 \\
\hline & 0 & 0 \\
\hline \multirow{2}{*}{ Significant corporate actions } & 7,2 & 7,2 \\
\hline & 0 & 0 \\
\hline \multirow{2}{*}{ Disclosure by corporation } & 12,2 & 12,2 \\
\hline & 0 & 0 \\
\hline \multirow{2}{*}{ Corporate Shareholder Register } & 14,4 & 14,4 \\
\hline & 0 & 0 \\
\hline \multirow{2}{*}{$\begin{array}{l}\text { Control over financial and economic activity of the } \\
\text { corporation }\end{array}$} & 4 & 4 \\
\hline & 0 & 0 \\
\hline \multirow{2}{*}{ Dividend policy of the corporation } & 5,8 & 5,8 \\
\hline & 0 & 0 \\
\hline
\end{tabular}

4. The program generates a summary table (Table 4) that contains the control and final value for each of the 12 indicators of corporate governance, as well as the estimated total value of the level of corporate governance for a specific corporate structure.

Table 4. Assessment of the level of corporate governance in ensuring corporate security 


\begin{tabular}{|l|l|c|}
\hline \multirow{2}{*}{ Corporate Conflict Resolution } & \multicolumn{1}{|c|}{7,8} & \multicolumn{1}{|c|}{7,8} \\
\cline { 2 - 3 } & \multicolumn{1}{|c|}{0} \\
\hline \multirow{2}{*}{ TOTAL } & $\begin{array}{l}\text { Calculated value of the } \\
\text { corporate governance } \\
\text { indicator, } K_{1}\end{array}$ & 100 \\
\cline { 2 - 3 } & $\begin{array}{l}\text { Calculated value of the } \\
\text { corporate governance } \\
\text { indicator, taking into } \\
\text { account the weights of the } \\
\text { respondent, } K_{2}\end{array}$ & 0 \\
\hline
\end{tabular}

Source: Designed by the authors

The table shows clearly how the level of the final value of a specific indicator of the level of corporate governance differs from the control one. The value of the calculated level of corporate governance characterizes the quality of governance in the corporate structure as a whole.

\section{Model of corporatization of corporate structures within the framework of consolidation strategies}

The main sources of the effect of using consolidation strategies in order to ensure sustainable development are to reduce production costs and to increase profitable parts.

Reduced production costs are provided at the expense of (Bruner, R. F. (2004; Creswell, 2008):

- the release of non-core and unloaded capacities, the realization of released property assets and their exclusion beyond the tax base;

- the release of functionally duplicate workers;

- the use of privileges and discounts due to demand for credit resources, insurance services, used raw materials, materials, completing products, and so on;

- the use of schemes of intracooperative deliveries at exclusive prices and price agreements;

- the use of the consolidated corporate balance in order to reduce tax deductions.

An increase in the profit part is provided by:

- obtaining new incomes (from the sale of the released property or leasing it);

- elimination of the effect of competitive price reduction, including according to the dumping scheme;

- increase of investment attractiveness of enterprises for portfolio investors;

- increase of attractiveness for customers due to increased reliability of supply and commodity products and increase sales volumes.

Eventually, corporatization companies acquire new individual properties, called "immanent" effect $\left(E_{i m m}\right)$ and the overall systemic "emergent" effect $\left(E_{e m}\right)$.

Immanent effect arises under the influence of a set of factors determined by the measures taken at each of the enterprises in the process of creating a corporation (Zaremba, and Płotnicki, 2016; Hamza, et. al. 2016). These factors can be classified in three groups:

1. factors of increasing the technical level of production and products;

2. factors of improving the organization of production, labor, management improvement;

3. intracorporate factors.

The emergent effect is characterized by the emergence of the newly created corporate structure of economic integrity inherent in companies that make up it.

It should be noted that the term "emergent effect" corresponds to the term, which is more often used, namely the "synergy effect" (from Greek synergos which means acting together). The difference in the effect of synergy from the emergent one is that it is characterized by sharper deviations of the resulting value of the effect in the 
positive or negative side due to significant differences in the potentials of corporatized enterprises (Hietala, et. al. (2003).

An assessment of the economic effect of emergence or synergy $\left(E_{s}\right)$ when applying a consolidation strategy can be presented as:

$$
E_{s}=E_{\text {enlarg. }}+E_{\text {devel. }}+E_{g d}
$$

where:

$-E_{\text {enlarg. }}$ is the effect of enlarging the scale of industrial activity and the unification of industrial capital;

$-E_{\text {devel }}^{\text {enlarg. }}$ is effect of corporation development;

$-E_{g d .}$ is the effect of the combined influence of factors of growth and development on vertical integration.

The values of the constituents of the formula (12) can be represented as:

$$
E_{\text {enlarg. }}=E_{\text {scale }}+E_{\text {ic. }}
$$

where:

$-E_{\text {scale }}$ - the effect of enlarging the scale of industrial activity of corporation;

$-E_{i c .}-$ the effect of the merger of industrial capital of the corporation.

The value of $E_{\text {devel. }}$ of the formula (12) can be represented as:

$$
\begin{aligned}
& E_{\text {devel. }}=E_{s t r .}+E_{\text {org. }}+E_{g o v .} \\
& E_{s t r .}=E_{d i v .}+E_{p e r .} \\
& E_{\text {org }}=E_{c o o p .}+E_{s p .} \\
& E_{g o v .}=E_{m}+E_{c s .}+E_{c o r}
\end{aligned}
$$

The value of $E_{g d .}$ of the formula (12) can be represented as:

$$
E_{g d .}=E_{v i}+E_{b i c}
$$

Let us explain the content of component formulas (15-18):

$-E_{s t r}$ is the strategic effect of corporation activity;

$-E_{\text {org }}$ is the effect of improving the organizational structure';

$-E_{\text {gov. }}$ is the effect of improving the corporate governance system;

$-E_{d i v}$ is the effect of diversifying the activities of the corporation;

$-E_{\text {per }}$ is the effect of peripheral development: branch network, dealer network;

$-E_{\text {coop. }}^{\text {per. }}$ is the effect of the development of internal cooperation of the corporation;

$-E_{s p .}$ is the effect of specialization within the corporation;

$-E_{m}$ is the effect of the functioning of the general management system;

$-E_{c s}$ is the effect of corporate consolidation reporting;

$-E_{c o r}$ is the effect of the coordinated actions of the corporation in the industry and in the market;

$-E_{v i .}$ is the effect of vertical integration;

$-E_{b i c}$ is the effect of combining bank and industrial capital.

Measures for each of the listed factors of an emergent (synergistic) effect make it possible to:

- coordinate supply and provide savings on taxes through integration;

- minimize transaction costs;

- diversify production; 
- improve specialization of production;

- restructure production with market orientation;

- form new relations of ownership with their influence on the management and organization of activities;

- solve the problem of asymmetry of information within the corporation over non-payment;

- control financial flows through the banks in the corporation;

- reduce the cost of borrowed capital within the corporation;

- increase the contractual discipline within the corporation by increasing the confidence in mutual capital participation (guarantee of contractual obligations);

- improve management on the ways of strategic planning of corporation development (Cho, et. al. 2016; Ogada, et. al. 2016).

It is possible to determine the total emergent (synergetic) effect by the formula (Hamza, et. al. 2016):

$$
E_{s .}=P N+E_{e}+E_{n}+E_{d}
$$

where:

$-P N$ is the estimated additional income from strategic measures;

$-E_{e}-$ saving current production and non-production costs;

$-E_{n}$ - saving tax payments;

$-E_{d}-$ other types of savings.

Consolidated synergistic strategy effect can be calculated using discounting effects each year by the formula:

$$
C=C_{n} \times(1+r)^{n}
$$

where:

$-r$ is an interest rate;

$-n$ is a number of years since the merger of companies.

It is necessary to make a comprehensive assessment of various integration options based on qualitative (content) and quantitative (formalized) characteristics of the project and all its participants in the basis of decisions on the economic feasibility of the creation of corporate consolidated systems.

The organizational project for a corporation is considered justified, and integration is appropriate if the main groups of criteria meet the criteria for assessing the benefits of integration (Bjuggren, et. al. 2007):

- criteria of justification and expediency of creation of the corporate integrated system;

- criteria of efficiency and stability of the corporation;

In addition, when comparing different projects and choosing the best one, they should also be analyzed using the following indicators:

- net present value $(N P V)$;

- profitability index $(P I)$;

- internal rate of return (IRR);

- payback period of the project.

Net present value $(N P V)$ is defined as the sum of current effects for the entire estimated period, is given to the initial step, or as an overrun of integral results over integral costs. The value of $N P V$ at the constant rate of discount $(E)$ is calculated by the formula:

$$
E=\text { ЧДД }=\sum_{t=0}^{T}\left(R_{t}-B_{t}\right) \times \frac{1}{(1+E)^{t}} \text {, }
$$

where: 
$-R_{t}$ is the results achieved at the $t$-th step of the calculation;

$-B_{t}$ is costs incurred at the same step;

$-T$ is a calculation horizon (equal to the number of step of calculation, at which the object is being evaluated); $E_{t}=\left(R_{t}-B_{t}\right)$ is the effect achieved at the $t$-th step of the calculation (Oyerogba, et. al. 2014).

If $N P V$ of the corporatization program at a given rate of discount is positive, it may be of interest to the investor. The greater $N P V$, the more effective the project is. If the program is implemented with a negative $N P V$, the investor will suffer losses, that is, the program is ineffective. In practice, for the purpose of defining $N P V$, a modified formula is often used, in which capital investments are excluded from $P N$. In this case, $P N^{*}$ denotes the costs of the t-th step of calculation, provided that capital investment does not include them. Then the value of $N P V$ is determined by the formula

$$
\text { ЧДД }=\sum_{t=0}^{T}\left(R_{t}-B_{t}\right) \times \frac{1}{(1+E)^{t}}-K
$$

where:

$-K$ is an amount of discounted capital investments;

$-B_{t}$ is the costs of the $\mathrm{t}$-th step of calculation, provided that capital investment does not include them.

The modified indicator of $N P V$ expresses the difference between the sum of the resulted effects and the time brought to the same time by the amount of capital investments $(K)$.

The profitability index $(P I)$ of the program is defined as the ratio of the sum of the reduced effects to the value of capital investments by the formula:

$$
I \Pi=\frac{1}{K} \sum_{t=0}^{T}\left(R_{t}-3_{t}^{*}\right) \times \frac{1}{(1+E)^{t}}
$$

The profitability index is closely related to $N P V$. It is constructed from the same elements and its value is related to the value of $N P V$ : if $N P V$ is positive, then $P I>1$ and vice versa. If $P I>1$, the production scheme is effective, if $P I<1$ it is ineffective.

The internal rate of return (IRR) of the corporatization program is the norm of discount $(E)$, in which the value of the reduced effects is equal to the reduced capital investment, ie $(I R R)$ is the solution of the equation (24):

$$
\operatorname{IRR}=\sum_{t=0}^{T} \frac{R_{t}-B_{t}}{(1+E)^{t}}=\sum_{t=0}^{T} \frac{K_{t}}{(1+E)^{t}}
$$

$I R R$ of the corporatization program defines the upper limit for the investor's rate of return on capital invested in this project (Oyerogba, et. al. 2014).

In the case when the investor requires a rate of return on capital of less than or equal to $I R R$, investment in this program is justified. Otherwise, investments in this program are inappropriate. In practice, IRR is often determined analytically, as the threshold value of the program's profitability, which ensures zero $N P V$ calculated for the lifetime of the investment. This is done by the selection method, that is, by overcoming different thresholds of profitability. The project is considered cost-effective at the value of IRR not lower than the initial threshold value. It is believed that the difference in objectives and conditions of the implementation of the corporatization program also affects the choice of the minimum level of return on capital investments (Gupta, P. G. (2012); Drobyazko S. (2018)). The payback period is a minimum period of time (from the beginning of the program), after which the integral effect remains not negative. The payback period should be determined using the discount method. 
As already noted earlier, the task of selecting enterprises in the created integrated system is two-dimensional and should be solved in two stages. Therefore, at the second stage, there is the problem of selecting partners from a set of competitive companies. The basis for such selection should be taken as much as possible, the resulting effect during their operation. This determines the need to select a criterion for such a set (Makedon, 2012).

Based on these recommendations, according to the optimization criterion considered by us, it is possible to adopt a discounted income indicator, and the decision method is the method of ranking the initial set of enterprises. In order to solve this problem, we first determine the efficiency of each unit of investment (conventional currency) by the formula:

$$
\frac{E_{i}}{U_{i}}
$$

where:

$-E_{i}$ is the efficiency of the $\mathrm{i}$-th particular business structure consisting of a consolidated system;

$-U_{i}$ is a necessary investment in a specific $\mathrm{i}$-th enterprise structure with its functioning in the consolidated system.

Or vice versa, we determine the relationship $\frac{U_{i}}{E_{i}}$. After that, we form the following series:

$$
\frac{E_{1}}{U_{1}} \geq \frac{E_{2}}{U_{2}} \geq \frac{E_{3}}{U_{3}} \geq \ldots \geq \frac{E_{i}}{U_{i}} \geq \ldots \geq \frac{E_{n}}{U_{n}}
$$

Or inversed set:

$$
\frac{U_{1}}{E_{1}} \leq \frac{U_{2}}{E_{2}} \leq \frac{U_{3}}{E_{3}} \leq \ldots \leq \frac{U_{i}}{E_{i}} \leq \ldots \leq \frac{U_{n}}{E_{n}}
$$

Then we create series of companies; starting with the first, as long as the sum of required investment for all companies will not equal (or approximately equal) to the financial resources of the corporation that can be used to create an integrated series. As a result, we receive series of companies, whose functioning provides the maximum economic effect (Tvaronavičienè, 2018).

Consequently, a formed set of business structures should satisfy the following two inequalities:

$$
\left\{\begin{array}{l}
\frac{E_{1}}{U_{1}} \geq \frac{E_{2}}{U_{2}} \geq \frac{E_{3}}{U_{3}} \geq \ldots \geq \frac{E_{i}}{U_{i}} \geq \ldots \geq \frac{E_{n}}{U_{n}} \\
\sum_{i=1}^{k} U_{i} \leq U_{c}
\end{array}\right.
$$

Or inequalities: 


$$
\left\{\begin{array}{l}
\frac{U_{1}}{E_{1}} \leq \frac{U_{2}}{E_{2}} \leq \frac{U_{3}}{E_{3}} \leq \ldots \leq \frac{U_{i}}{E_{i}} \leq \ldots \leq \frac{U_{n}}{E_{n}} \\
\sum_{i=1}^{k} U_{i} \leq U_{c}
\end{array}\right.
$$

where:

$-U_{c}$ is a total financial resources of the corporation for the consolidation project;

$-K$ is a number of entrepreneurial structures that are part of the group.

\section{Rationalization of a set of business structures for inclusion in a united corporate structure}

The company was supposed to form an optimal set of business entities that claim to be part of the consolidated system that was being built, provided that the total financial resources that the company has to consolidate is $\$$ 125,000 million. The rest of the initial data for calculation is shown in Table 5.

Table 5. Economic indicators of entrepreneurial structures that are applying for inclusion in a consolidation association

\begin{tabular}{|c|c|c|c|c|}
\hline $\begin{array}{c}\text { Candidate } \\
\text { number }\end{array}$ & $\begin{array}{c}\text { Investment need, } \\
\text { million dollars USA }\end{array}$ & $\begin{array}{c}\text { Net discounted income, } \\
\text { million dollars USA }\end{array}$ & $\begin{array}{c}\text { Need to invest \$ 1 US } \\
\text { of net discounted income }\end{array}$ & 2,0 \\
\hline 1 & 4000 & 2000 & 3,33 & $\begin{array}{c}\text { Company } \\
\text { rank }\end{array}$ \\
\hline 2 & 10000 & 3000 & 1,66 & 10 \\
\hline 3 & 25000 & 15000 & 5,0 & 13 \\
\hline 4 & 20000 & 4000 & 3,26 & 12 \\
\hline 5 & 15000 & 4600 & 1,67 & 5 \\
\hline 6 & 30000 & 18000 & 1,82 & 8 \\
\hline 7 & 8000 & 4400 & 2,8 & 11 \\
\hline 8 & 14000 & 5000 & 1,94 & 9 \\
\hline 9 & 7000 & 3600 & 1,25 & 1 \\
\hline 10 & 6000 & 4800 & 1,79 & 7 \\
\hline 11 & 5000 & 2800 & 1,71 & 6 \\
\hline 12 & 12000 & 7000 & 1,5 & 2 \\
\hline 13 & 15000 & 10000 & 1,6 & 3 \\
\hline 14 & 8000 & 5000 & 89200 & \\
\hline Total: & 179000 & & & \\
\hline
\end{tabular}

Source: calculation authors

Table 5 shows that the initial set of entrepreneurial structures requires investments in the amount of $\$ 179,000$ million dollars. The amount of financial resources available to the corporation is $\$ 125,000$ million.

Consequently, the whole set of companies in Table 5 can not be included in the created structure. Therefore, it is necessary to select from the initial set those companies that would provide the maximum economic effect in the functioning of the future consolidated system.

Table 5 shows not only the initial data of this example, but also the results of calculating the investment need for each dollar. US investment, expected economic effect, as well as the rank of each company, which is determined by the ratio $\frac{E_{i}}{U_{i}}$. Based on the calculated rank and initial data, we form a rational set of business structures, inclusion of which is expedient to include from defined set. The results of organization of such a set of formation of business structures are summarized in Table 6. 
Table 6. Formation of a rational set of business structures for inclusion in a consolidation association

\begin{tabular}{|c|c|c|c|c|c|}
\hline $\begin{array}{c}\text { Candidate } \\
\text { rank }\end{array}$ & $\begin{array}{c}\text { Number of } \\
\text { object in the } \\
\text { initial set }\end{array}$ & $\begin{array}{c}\text { Investment need, } \\
\text { million dollars } \\
\text { USA }\end{array}$ & $\begin{array}{c}\text { The need for investment } \\
\text { (by increment), million } \\
\text { dollars USA }\end{array}$ & $\begin{array}{c}\text { Net discounted } \\
\text { income, million } \\
\text { dollars USA }\end{array}$ & $\begin{array}{c}\text { Net discounted income } \\
\text { (by increment), } \\
\text { million dollars USA }\end{array}$ \\
\hline 1 & 10 & 6000 & 6000 & 4800 & 4800 \\
\hline 2 & 13 & 15000 & 21000 & 10000 & 14800 \\
\hline 3 & 14 & 8000 & 29000 & 5000 & 19800 \\
\hline 4 & 3 & 25000 & 54000 & 15000 & 34800 \\
\hline 5 & 6 & 30000 & 84000 & 18000 & 52800 \\
\hline 6 & 12 & 12000 & 96000 & 7000 & 59800 \\
\hline 7 & 11 & 5000 & 101000 & 2800 & 62600 \\
\hline 8 & 7 & 8000 & 109000 & 3600 & 67000 \\
\hline 9 & 9 & 7000 & 116000 & 2000 & 70600 \\
\hline 10 & 1 & 4000 & 120000 & 5000 & 72600 \\
\hline 11 & 8 & 14000 & 134000 & 4600 & 77600 \\
\hline 12 & 5 & 15000 & 149000 & 3000 & 82200 \\
\hline 13 & 2 & 10000 & 159000 & 4000 & 85200 \\
\hline 14 & 4 & 20000 & 179000 & & 89200 \\
\hline
\end{tabular}

Source: calculation by authors

From the Table 6, it should be noted that with financial resources of $\$ 125,000$ million dollars, only 10 candidates with numbers in the initial set should be included in the set of business structures that are being formed: 10, 13, $14,3,6,12,11,7,9,1$. In this case, the reserve contains $\$ 5.0$ million dollars.

The total expected net disposable income in the functioning of the listed candidates in the consolidated system will make $\$ 5$ - 72600 million dollars, as it follows from the same table.

For comparison, let us create the most favorable set of business structures, which is included in the organized system.

Obviously, when forming such a set, the initial set of candidates for inclusion should be ranked not by the degree of reduction, but by the degree of growth in investment needs, that is, it should first be included in the molded set of companies with the maximum need for investments per unit of NPV. Then it is a company following it and so on, until the total investment need again does not turn out to be equal (or approximately equal) to the resources available. For such a formation, for the initial data, we accept the same data in Table 5. And the results of formation of such a set are summarized in Table 7.

Table 7. The results of formation of a set of business structures for inclusion in a consolidation association

\begin{tabular}{|c|c|c|c|c|c|}
\hline $\begin{array}{c}\text { Candidate } \\
\text { rank }\end{array}$ & $\begin{array}{c}\text { Number of } \\
\text { object in the } \\
\text { initial set }\end{array}$ & $\begin{array}{c}\text { Investment need, } \\
\text { million dollars USA }\end{array}$ & $\begin{array}{c}\text { The need for investment } \\
\text { (by increment), million } \\
\text { dollars USA }\end{array}$ & $\begin{array}{c}\text { Net discounted } \\
\text { income, million } \\
\text { dollars USA }\end{array}$ & $\begin{array}{c}\text { Net discounted income } \\
\text { (by increment), } \\
\text { million dollars USA }\end{array}$ \\
\hline 1 & 4 & 20000 & 20000 & 4000 & 4000 \\
\hline 2 & 2 & 10000 & 30000 & 3000 & 7000 \\
\hline 3 & 5 & 15000 & 45000 & 4600 & 11600 \\
\hline 4 & 8 & 14000 & 59000 & 5000 & 16600 \\
\hline 5 & 1 & 4000 & 63000 & 2000 & 18600 \\
\hline 6 & 9 & 7000 & 70000 & 3600 & 22200 \\
\hline 7 & 7 & 8000 & 78000 & 4400 & 2600 \\
\hline 8 & 11 & 5000 & 83000 & 7000 & 2900 \\
\hline 9 & 12 & 12000 & 95000 & & 36400 \\
\hline
\end{tabular}




\begin{tabular}{|c|c|c|c|c|c|}
\hline 10 & 6 & 30000 & 125000 & 18000 & 54400 \\
\hline 11 & 3 & 25000 & 150000 & 15000 & 69400 \\
\hline 12 & 14 & 8000 & 158000 & 5000 & 74400 \\
\hline 13 & 13 & 15000 & 173000 & 10000 & 84400 \\
\hline 14 & 10 & 6000 & 179000 & 4800 & 89200 \\
\hline
\end{tabular}

Source: calculation by authors

From the Table 7 we can see that the set formed should include the same 10 candidates, but with the following initial numbers: $4,2,5,8.1,9,7,11,12,6$. This set of companies with their functioning in the structure of the system being organized, will provide NPV in the amount of $\$ 54,400$ million dollars.

Comparing this amount with the amount provided by the previously formed set (see Table 4) at $\$ 72600$ million dollars, we can see that the difference is significant. This example confirms the expediency and validity of the predicted method for the formation and organization of integrated structures.

\section{Conclusions}

It has been established by the study that existing methods for assessing the level of corporate governance do not fully meet market needs. On the basis of the obtained results, the scientific and methodological principles have been developed in order to assess the quality of corporate governance level and to ensure adequate corporate security within the framework of the use of consolidation strategies of sustainable development on the basis of 12 criteria: 1) the corporation's readiness to adhere to the principles of corporate behavior; 2) structure of corporate property; 3) General Meeting of Shareholders; 4) Board of Directors of the Corporation; 5) executive authority; 6) corporate secretary; 7) significant corporate actions; 8) disclosure by corporation; 9) Corporate Shareholder Register; 10) control over financial and economic activity of the corporation; 11) dividend policy of the corporation; 12) Corporate Conflict Resolution.

It has been determined that the main sources of the effect of combining business structures within the limits of consolidation strategies is reducing the production costs and increasing the level of corporate security.

It has been substantiated that entrepreneurial structures acquire new individual properties in the course of corporatization: there is an "immanent" effect $\left(\mathrm{E}_{\text {imm }}\right)$ (it arises under the influence of a set of factors determined by the measures taken at each of the enterprises in the process of creation of the corporation) and the overall systemic "emergent" effect $\left(\mathrm{E}_{\mathrm{em}}\right)$ (it characterized by the emergence of the newly created corporate structure of economic integrity, inherent in each corporate structure that will form a corporation).

The model of corporatization of business structures has been developed in the context of consolidation and development security strategies; the model has been tested on the example of the formation of a new company.

\section{References}

Acur, N., \& Englyst, L. (2006). Assessment of strategy formulation: How to ensure quality in process and outcome International Journal of Operations \& Production Management, 26(1), 69-91. https://doi.org/10.1108/01443570610637021

Ardalan, F., Almasi, N. A., Atasheneh, M. (2017). Effects of contractor and employer's obligations in buy back contracts: case study of oil exporting country. Entrepreneurship and Sustainability Issues, 5(2), 345-356. http://doi.org/10.9770/jesi.2017.5.2(13)

Alam, A., Khan S. and Zafar, F. (2014). Strategic Management: Managing Mergers \&Acquisitions. International Journal of BRIC Business Research, 3, 1-10 https://doi.org/10.1080/0953732022000002122

Bjuggren, P.O., Eklund, J.E., \& Wiberg, D. (2007). Ownership structure, control and firm performance: The effects of vote-differentiated shares. Applied Financial Economics, 17(16), 1323-1334. https://doi.org/10.1080/09603100600993737

Bradley, M. and Sundaram, A. (2006). Acquisitions and performance: a re-assessment of the evidence, SSRN Working paper, Duke 
University. https://doi.org/10.2139/ssrn.592761

Bruner, R. F. (2004). Applied Mergers and Acquisitions, University of Virginia Publications. URL: https://faculty.darden.virginia.edu/ brunerb/oldsite2004/publications.htm

Cho, S. Y., Arthurs, J. D., Townsend, D. M., Miller, D. R., \& Barden, J. Q. (2016). Performance deviations and acquisition premiums: The impact of CEO celebrity on managerial risk-taking. Strategic Management Journal, 37(13), 2677-2694. https://doi.org/10.1002/ smj. 2468

Collis, D.J. \& Cynthia, A.M. (2005). Corporate strategy: A resource-based approach. Irwin. URL: https://www.hbs.edu/faculty/Pages/ item.aspx?num $=15086$

Cravens, D. W. \& Piercy, F.N. (2009). Strategic marketing, (Ninth Edition). New York: McGraw Hill. URL: https://archive.org/details/ strategicmarketi00crav_0

Creswell, J. (2008). Educational research: Planning, conducting, and evaluating quantitative and qualitative research. New Jersey: Pearson, Merrill Prentice Hall.

Dodgson, M. (2018). Technological collaboration in industry: strategy, policy and internationalization in innovation. Routledge. https:// doi.org/10.4324/9781351265607

Douma, S., George, R., \& Kabir, R. (2006). Foreign and domestic ownership, business groups, and firm performance: Evidence from a large emerging market. Strategic Management Journal, 27(7), 637-657. https://doi.org/10.1002/smj.535

Drobyazko S. (2018a). Modeling expenditure to provide economic security of insurance companies. International scientific journal "Internauka”. Series: “Economic Sciences” №3. https://doi.org/10.25313/2520-2294-2018-3-4785

Drobyazko S. (2018b). Insurance market development as a factor of the economic safety of the insurance sector enterprises. Efektyvna ekonomika, [Online], vol. 8, available at: http://www.economy.nayka.com.ua/?op=1\&z=6928

Enterprise Risk Management-Integrated Framework: Executive Summary (2004). Retrieved from http://www.coso.org/documents/ coso_erm_executivesummary.pdf

Gupta, P. G. (2012). Mergers and Acquisitions (M\&A): The strategic concepts for the nuptials of corporate sector. Innovative Journal of Business and Management, 1, 60-68. Retrieved from https:/www.innovativejournal.in/index.php/ijbm/article/view/389

Hamza, T., Schaier, A., and Thraya, M. H. (2016). How do takeovers create synergies? Evidence from France. Studies in Business and Economics, 11(1), 54-72. https://doi.org/10.2307/3666381

Hasanudin, A.I., Yuliansyah, Y., Said, J., Susilowati, Ch., Muafi. (2019). Management control system, corporate social responsibility, and firm performance. Entrepreneurship and Sustainability Issues, 6(3), 1154-1168. http://doi.org/10.9770/jesi.2019.6.3(21)

Hitt, A.M., Hoskisson, E.R. \& Ireland, R.D. (2007). Management of strategy. Thomson, South-Western. URL: https://pracownik.kul.pl/ files/12439/public/1_Hitt.StrategicManagement.pdf

Hietala, P., Kaplan, S. N. and Robinson, D. T. (2003). What is the price of hubris? Using takeover battles to infer overpayments and synergies. Financial Management, 32, 5-31. https://doi.org/10.1515/sbe-2016-0005

Hu, Y., \& Izumida, S. (2008). Ownership concentration and corporate performance: A causal analysis with Japanese panel data. Corporate Governance: An International Review, 16(4), 342-358. https://doi.org/10.1111/j.1467-8683.2008.00690.x

Kazansky, R., Andrassy, V. (2019). Conflict resolution approaches towards smart sustainability of internal relations. Entrepreneurship and Sustainability Issues, 6(3), 1268-1284. https://doi.org/10.9770/jssi.2019.6.3(29)

Kiymaz, H., Baker, H. (2008). Short-term Performance, Industry Effects, and Motives: Evidence from Large M\&As. Quarterly Journal of Finance and Accounting, 47, 17-44. URL: https:/www.questia.com/read/1G1-188275738/short-term-performance-industry-effectsand-motives

Kordík M., Kurilovská, L. (2019). Content of a Intra Group Compliance Agreement as a risk mitigating factor. Entrepreneurship and Sustainability Issues, 6(3), 1095-1104. http://doi.org/10.9770/jesi.2019.6.3(10)

Makedon, V. (2012). Institutional prerequisites of forming the market of mergers and acquisitions of companies in the countries of central and eastern Europe. Zeszyty Naukowe Wyższej Szkoły Zarządzania Ochroną Pracy w Katowicach, 1(8), 21-31. URL: http://yadda.icm.edu.pl/ yadda//element/bwmeta1.element.baztech-article-BUS6-0042-0002?printView=true 
Makedon, V., Korneyev, M. (2014). Improving methodology of estimating value of financial sector entities dealing in mergers and acquisitions. Investment Management and Financial Innovations, 11(1), 44-55. URL: https://www.researchgate.net/ publication/289853616_Improving_methodology_of_estimating_value_of_financial_sector_entities_dealing_in_mergers_and_ acquisitions

Ogada, A., Achoki, G. and Njuguna, A. (2016). Effect of diversification on the Financial Performance of Merged Institutions. American Journal of Finance, 1(2), 91-106. URL: https://pdfs.semanticscholar.org/97f3/c7ab71e8269385ad26b9e61ca665a3ff234e.pdf

Oyerogba, E.O., Olaleye, O.M., \& Solomon, A.Z. (2014). The effect of ownership concentration on firm value of listed companies. IOSR Journal of Humanities and Social Science (IOSR-JHSS), 19, 90-96. URL: https:/www.abacademies.org/articles/ownership-structureand-corporate-performance-of-multinational-banks-evidence-from-nigeria-7621.html

Petrishcheva, I.V. (2011). Industrial Cooperation in the Context of Interaction of Small and Large Enterprises: Essence and Forms. Almanac of Modern Science and Education, 1, 168-170. https://doi.org/10.9770/jesi.2018.5.3(4)

Rothaermel, F.T. (2015). Strategic management. McGraw-Hill Education. URL: https://www.bookdepository.com/StrategicManagement-Concepts-Frank-T-Rothaermel/9780077645069

Statistics on M\&A deals (2018). Available on the Internet: http://www.statista.com/search/m\%26a+deals/cat/11/

Tvaronavičienè, M. (2018). Toward efficient policy making: forecasts of vulnerability to external global threats, Journal of Security and Sustainability Issues 7(3): 591-600. https://doi.org/10.9770/jssi.2018.7.3(18)

Thompson, Robert B. (2010). Mergers and Acquisitions: Law and Finance, Aspen Pub.

Vachon, D. (2007). Mergers \& Acquisitions, Riverhead Hardcover.

Zaremba, A. and Płotnicki, M. (2016). Mergers and acquisitions: Evidence on postannouncement performance from CEE stock markets. Journal of Business Economics and Management, 17(2), 251-266. https://doi.org/10.3846/16111699.2015.1104384

Short biographical note about the contributors at the end of the article:

Maryna CHORNA, Dr. Hab. (Economics), Professor, Head of the Department of Economics of Catering and Trade Enterprisesof the Kharkov State University of Food Technology and Trade

ORCID ID: orcid.org/ 0000-0001-5387-7832

Roman BUHRIMENKO, PhD in economics, Assistant Professor, Kharkov State University of Food Technology and Trade ORCID ID: orcid.org/0000-0002-0973-0814

Polina SMIRNOVA, PhD in economics, Assistant Professor, Kharkov State University of Food Technology and Trade ORCID ID: orcid.org/0000-0001-8567-7915

Svetlana SHYNKAR, PhD in economics, Assistant Professor, Kharkov State University of Food Technology and Trade ORCID: ID: orcid.org/0000-0002-0580-7845

Iryna ZHUVAKINA, Ph.D. (Economics), Associate Professor, Pervomaysk branch of the National University of Shipbuilding named after Admiral Makarov

ORCID ID: https:// 0000-0002-6701

This work is licensed under the Creative Commons Attribution International License (CC BY). http://creativecommons.org/licenses/by/4.0/ 